\title{
P2Y Purinoceptor 2
}

National Cancer Institute

\section{Source}

National Cancer Institute. P2Y Purinoceptor 2. NCI Thesaurus. Code C112488.

P2Y purinoceptor 2 (377 aa, $\sim 42 \mathrm{kDa}$ ) is encoded by the human P2RY2 gene. This protein plays a role in ligand-dependent activation of second messenger signaling pathways. 